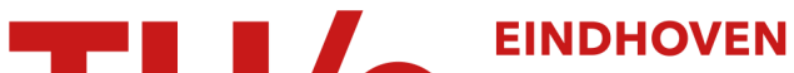 UNIVERSITY OF TECHNOLOGY
}

\section{Dynamic orientation of conjugated oligomers in nematic liquid crystalline matrices}

\section{Citation for published version (APA):}

Sariciftci, N. S., Lemmer, U., Vacar, D., Heeger, A. J., \& Janssen, R. A. J. (1997). Dynamic orientation of conjugated oligomers in nematic liquid crystalline matrices. Synthetic Metals, 84(1-3), 609-610.

https://doi.org/10.1016/S0379-6779\%2896\%2904074-X, https://doi.org/10.1016/S0379-6779(96)04074-X

DOI:

10.1016/S0379-6779\%2896\%2904074-X

10.1016/S0379-6779(96)04074-X

Document status and date:

Published: 01/01/1997

\section{Document Version:}

Publisher's PDF, also known as Version of Record (includes final page, issue and volume numbers)

\section{Please check the document version of this publication:}

- A submitted manuscript is the version of the article upon submission and before peer-review. There can be important differences between the submitted version and the official published version of record. People interested in the research are advised to contact the author for the final version of the publication, or visit the $\mathrm{DOI}$ to the publisher's website.

- The final author version and the galley proof are versions of the publication after peer review.

- The final published version features the final layout of the paper including the volume, issue and page numbers.

Link to publication

\section{General rights}

Copyright and moral rights for the publications made accessible in the public portal are retained by the authors and/or other copyright owners and it is a condition of accessing publications that users recognise and abide by the legal requirements associated with these rights.

- Users may download and print one copy of any publication from the public portal for the purpose of private study or research.

- You may not further distribute the material or use it for any profit-making activity or commercial gain

- You may freely distribute the URL identifying the publication in the public portal.

If the publication is distributed under the terms of Article 25fa of the Dutch Copyright Act, indicated by the "Taverne" license above, please follow below link for the End User Agreement:

www.tue.nl/taverne

Take down policy

If you believe that this document breaches copyright please contact us at:

openaccess@tue.nl

providing details and we will investigate your claim. 


\title{
Dynamic Orientation of Conjugated Oligomers in Nematic Liquid Crystalline Matrices
}

\author{
N. Serdar Sariciftci \\ Physikalische Chemie, Johannes Kepler Universitat Linz \\ Altenbergerstrasse 69, A-4040 Linz, Austria \\ $\mathrm{U}$. Lemmer \\ Sektion Physik, Luawig Maximilian Universität München, 80799 Germany \\ D. Vacar and A. J. Heeger \\ Institute for Polymers \& Organic Solids, University of California, Santa Barbara, CA 93106, U.S.A. \\ R. A. J. Janssen \\ Eindhoven University of Technology, 5600 Eindhoven, The Netherlands
}

\begin{abstract}
Polarized photoluminescence is observed from a host/guest system consisting of conjugated oligomers dissolved in nematic liquid crystalline matrices. In this system, conjugated oligomers (guest) exhibit an emission spectrum well separated from the emission of the liquid crystalline matrix (host) however polarized parallel to the orientation of the host matrix. The results clearly demonstrate the spontaneous orientation of the oligothiophenes along the director of the nematic matrix. Upon applying an electric field perpendicular to the direction of the spontaneous orientation, the oligomers are dynamically reoriented (switched) with the host resulting in switching of the polarized photoluminescence.
\end{abstract}

Keywords: Self-organization in macromolecules, optical absorption and emission spectroscopy, switches, polythiophene and derivatives

\section{Introduction}

Physical properties of conjugated polymer films are heavily influenced by the intrinsic disorder phenomena within the structure. With material quality getting better through high degree of uniformity of chemical coupling as well as through controlled recrystallization from solutions in the doped conducting state and further refining of the synthesis conditions, conducting polywers can now be prepared well on the metallic side of the disorder induced M-I transition [1-4]. Thus, creating macroscopic order within the conjugated polymeric structures has always been a continuing, important, scientific challenge.

The idea of using liquid crystalline host matrices for macroscopic orientation of guest molecules is quite well known (see for example [5] and references therein). Araya et al. showed that synthesis of polyacetylene in liquid crystalline matrices results in highly oriented materials [6]. Furthermore, synthetic efforts of modifying the side chains of a conjugated polymer with liquid crystalline side groups have been reported in detail (see for example [7-15] and references therein). Recently, polarized photoluminescence has been reported from liquid crystalline polymers with phenylenevinylene segments on the main chain[16]. T'aliani et al. reported on a liquid crystalline phase of the a-sexithienyl $\left(\mathrm{T}_{6}\right)$ above $\mathrm{T}=312 \mathrm{C}$ [17]. Molecules such as thiophencs and bithiophenes cmbedded in liquid crystalline matrices has been investigated with nuclear magnetic resonance techniques to obtain accurate structural information $[18,19]$.

In this contribution we report the macroscopic orientation of conjugated oligomers (six membered oligothiophenes; e.g. asexithienyl, $\left(T_{\sigma}\right)$ ) dissolved within a nematic liquid crystalline matrix (Fig.1). The orientation of the oligothiophenes can be dynamically switched with the host nematic matrix upon application of an electric field as observed through switching of the polarized photoluminescence of $\mathrm{T} 6$.

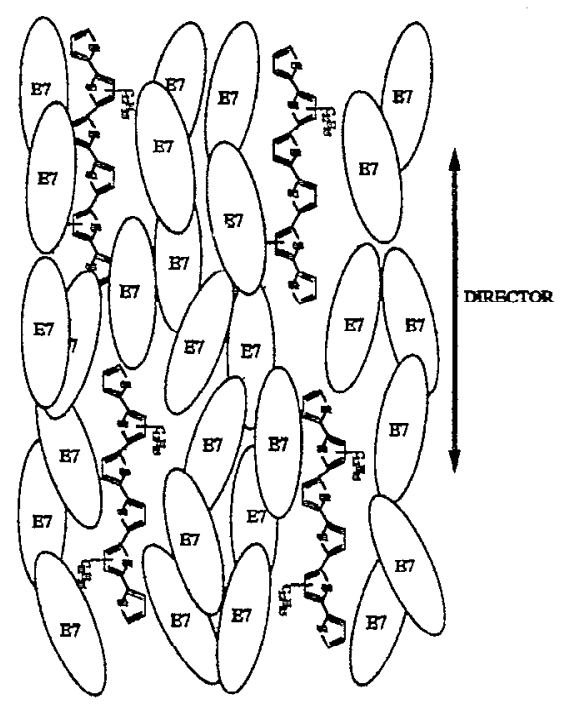

Fig. 1: Schematic illustration of the ordering of oligothiophenes (T6) within a homogeneously aligned nematic liquid crystalline matrix.

\section{Results \& Discussion}

The six membered oligothiophene used in the present study carry dodecyl substituents on different thiophene rings and is designated as $\mathrm{T}_{6} \mathrm{~d}(2,5)$. The synthesis has been described previously $[20,21]$. Details of the experiments are published elsewhere [22]. The liquid crystal cells filled with the solutions of $T_{6}$ in $E 7$ show uniform brightness under cross polarized microscope suggesting a homogeneous alignment of the liquid crystals. To estimate the achieved degree of homogeneous 
alignment of $\mathrm{T}_{6}$ in nematic matrix we performed linear dichroism experiments using polarized lineariy optical absorption and emission. Fig. 2 shows the polarization dependence of the emission spectra. The emission spectrum of $\mathrm{T}_{6}$ obtained by exciting and probing parallel to the rubbing direction (parallel to the director of the nematic matrix) is an order of magnitude stronger compared to the case where excitation and emission is perpendicular to the director. Since the active emission originates from the guest molecules, $T_{6}$, this result confirms the orientation of the guest within the nematic host.

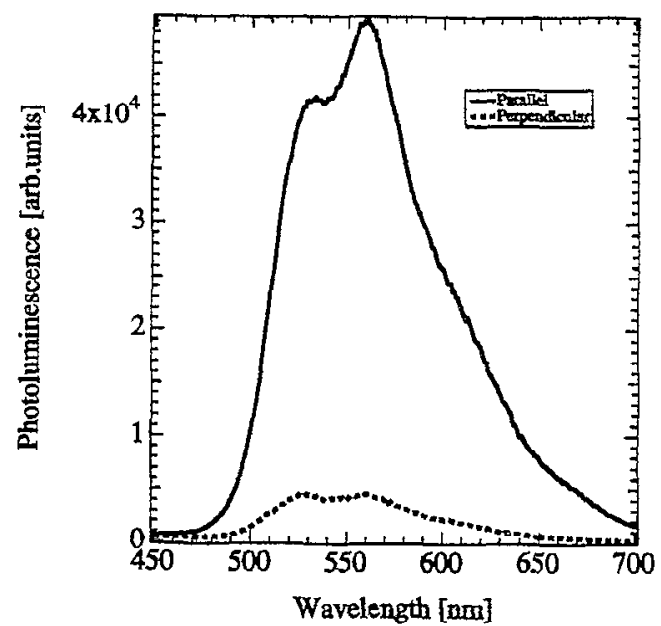

Fig. 2: Photoluminescence dichroism of $\mathrm{T}_{6}$ in $\mathrm{E} 7(10 \mu \mathrm{m}$ cell) obtained through a polarized excitation and emission, both parallel and both perpendicular to the rubbing direction (nematic director), respectively.

As shown in Fig. 3, the $\mathrm{T}_{6}$ molecules embedded into the $\mathrm{E} 7$ nematic host matrix can be dynamically reoriented by applying an electric field $18 \mathrm{~V}$ per $10 \mu \mathrm{m}$ thickness to the liquid crystal cells filled with the solutions. The quenching of the photoluminescence by the field is attributed to the reorientation of the T 6 molecules parallel to the electric field.

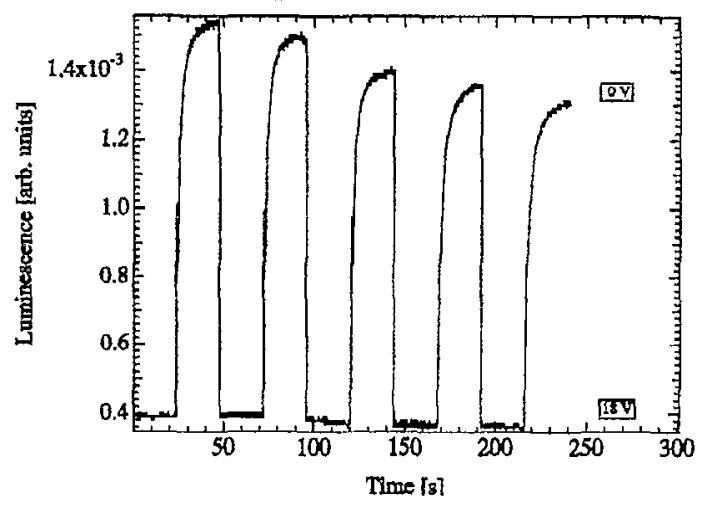

Fig. 3: Switching of the photoluminescence of $T_{6}$ in $E 7$ by switching an electric field $(18 \mathrm{~V} / 10 \mu \mathrm{m})$ on and off.

The possibility that an extended conjugated oligomer can be macroscopically aligned by simply embedding in a liquid crystalline matrix and utilizing the properties of the host opens up areas for detailed studies of the properties of conjugated oligomers and polymers using, for example,

i.) optical dichroism to get polarization information on the excited states, ii.) high resolution nuclear magnetic resonance spectroscopy to get anisotropic interactions,

iii.) electron spin resonance to get detailed parameter of the radical ions (polarons) and triplet states by doping and photoexcitation, respectively.

Furthermore, the combination of the liquid crystalline display technologies with the emerging new area of conjugated polymer light emitting diodes is interesting.

\section{Acknowledgements}

We acknowledge Jim Bourassa, Mark Urish and Günther Ahlers for valuable help. The oligothiophenes are generously provided by Philips Research Laboratories.

\section{References}

[1] M. Reghu, Y. Cao, D. Moses, and A. J. Heeger, Phys. Rev. $B$ 47, (1993) 1758 .

[2] C. O. Yoon, R. Menon, D. Moses, and A. J. Heeger, Phys. Rev. B 49, (1994) 10851.

[3] R. D. McCullough, R. D. Lowe, M. Jayaraman, and D. L. Anderson, J. Org. Chem. 58, (1993) 904.

[4] R. D. McCullough, S. Tristan-Nagle, S. P. Williams, R. D. Lowe, and M. Jayaraman, J. Am. Chem. Soc. 115, (1993) 4910.

[5] G. Meier, E. Sackmann, and J. G. Grabmaier, Applications of Liquid Crystals (Springer Verlag, Berlin, 1975).

[6] K. Araya, A. Mukoh, T. Narahara, and H. Shirakawa, Synth. Met. 14, (1986) 199.

[7] H. Goto, K. Akagi, H. Shirakawa, S.-Y. Oh, and K. Araya, Synth. Met. 71, (1995) 1899.

[8] K. Agaki, H. Goto, H. Shirakawa, T. Nishizawa, and K. Masuda, Synth. Met. 69, (1995) 33.

[9] F. Vicentini, M. Mauzac, R. Laversanne, P. Pochat, and J. P. Parneix, Liq. Cryst. 16, (1994) 721.

[10] L. Yu and Z. Bao, Adv. Mater. 6, (1994) 156.

[11] K. Yoshino, X. H. Yin, S. Morita, M. Nakazono, T. Kawai, M. Ozaki, S.-H. Jin, and S.-K. Choi, Jpn. J. Appl. Phys. 32, (1993) L1673.

[12] G. H. W. Milburn, C. Campbell, A. J. Shand, and A. R. Werninck, Liq. Cryst. 8, (1990) 623.

[13] Y. Ozcayir and A. Blumstein, J. Polym. Sci. Part A (Polymer Chemistry) 24, (1986) 1217.

[14] Y. Ozcayir, J. Asrar, S. B. Clough, and A. Blumstein, Mol. Cryst. Liq. Cryst. 138, (1986) 167.

[15] A. F. Garito, in Proc. SPIE, Advances in Materials for Active Optics, San Diego, CA, USA, SPIE Proceedings 567 (SPIE, 1985) 51.

[16] G. Lussem, R. Festag, A. Greiner, C. Schmidt, C. Unterlechner, W. Heitz, J. H. Wendorff, M. Hopmeier, and J. Feldmann, Adv. Mater. 7, (1995) 923.

[17] C. Taliani, R. Zamboni, G. Ruani, S. Rossini, and R. Lazzaroni, J. Mol. Elec. 6, (1990) 225.

[18] P. B. Liescheski and D. W. H. Rankin, J. Mol. Structure 178, (1988) 227.

[19] L. C. T. Beek, D. S. Zimmerman, and E. E. Burnell, Mol. Phys. 74, (1991) 1027.

[20] W. t. Hoeve, H. Wynberg, E. E. Havinga, and E. W. Meijer, J. Am. Chem. Soc. 113, (1991) 5887.

[21] E. E. Havinga, I. Rotte, E. W. Meijer, W. t. Hoeve, and H, Wynberg, Synth. Met. 41-43, (1991) 473.

[22] N. S. Sariciftci, U. Lemmer, D. Vacar, A. J. Heeger, R. A. J. Janssen, Adv. Mater., in press (1996). 